\title{
Rosencrantz and Guildenstern Are Dead: from Stage Script to Screen Presentation
}

\author{
Hongwei Chen \\ School of Foreign Studies, Beijing University of Science and Technology, Beijing, China \\ Email: rosechw@yahoo.com.cn
}

\begin{abstract}
Re-working on his reputation-establishing play in a new medium over the span of two decades after its first stage presentation, the film version of Rosencrantz and Guildenstern Are Dead (1991) demonstrates an extension as well as a variation of its original stage script, particularly in the aspect of Tom Stoppard's responses to the classical text of Shakespeare. Although the image of Shakespeare's dramatic text still haunts the story like a ghost, a carnival air of absurdity is added to the work, which makes Stoppard's motif of Shakespeare more ambiguous.
\end{abstract}

Index Terms — stage play, screen play, Shakespeare, subversive approach, haunting presence

\section{INTRODUCTION}

Being one of the most distinguished dramatists in the Post-War English drama, Tom Stoppard had quite a few of plays successfully presented on screen, such as The Human Factor (1979) adapted from Graham Greene's bestseller Brazil (1985), Empire of the Sun (1987) from the novel of the same name by J. G. Ballard, and Shakespeare in Love (1998), a great success co-scripted with Marc Norman. Among his screen plays, Rosencrantz and Guildenstern Are Dead (1967) is the only one scripted and directed by Stoppard himself. Re-working on his reputation-establishing play over the span of two decades after its first stage presentation and doing it in a new medium, the film version of Rosencrantz and Guildenstern Are Dead (1991) demonstrates an extension as well as a variation of original stage script, particularly in the aspect of Stoppard's responses to the classical text of Shakespeare. The implied meanings in the stage work get more explicitly expressed through the editing and encoding of the camera, which makes the motif of Stoppard's relation with Shakespeare more ambiguous.

\section{SCREEN PRESENTAtion AS A Re-CODING OF THE StAge Play}

As Egil Torqvist writes, the absence/presence of the editing-camera undoubtedly signifies the principal difference between stage and screen versions ${ }^{1}$. While the live performance of the former relies dominatingly on the verbal strength, a third perspective of camera is added to the film. Though both stage performance and film are visual art, a stage play is more verbal than cinema owing to its limitation in terms of visual display: "Words on the stage must be weighty enough to create a meaningful imaginary world with far less assistance from the visual than is the case on the screen." $\mathrm{Relying}$ mainly on the verbal, the power of the theatre lies much more in its capacity to represent the dramatic work by suggestion, while cinema, as a contrast, "reproduces phenomenon in its details, its minutiae, and the more the director reproduces these in their concrete, sensuous form, the closer he will be to his aim."3

So, compared with stage performance, screen presentation enjoys the obvious advantage of visual potentiality resulted from the flexibility of camera. Relying more on the visual than verbal, a totally new kind of acting style is required by the screen play: not only weighty speech in the stage play has to be changed to more economic one; an emphasis on the physical expressions of the characters is also required. As Erwin Panofsky writes, "the camera transforms the human physiognomy into a huge field of action where - given the qualification of the performers - every subtle movement of the feature, almost imperceptible from a natural distance, becomes an expressive event in visible space event in visible space and thereby completely integrates itself with the expressive content of the spoken word...." As Rod Whitmaker states, camera angle is largely dispositional. In a variety of ways "angle alters the terms under which the subject matter is to be viewed. Primarily, a change of angle alters the composition of the shot, and, thereby, the environment in which the principal subject is to be seen. This involves certain inclusions and exclusions of surrounding and qualifying matter. Beyond this, angle may be regarded as subjective, attitudinal, or intensifying." ${ }^{5}$ And

\footnotetext{
${ }^{1}$ Egil Tornqvist (1991), Transposing Drama. Basingstoke: Macmillan. p.175.

${ }^{2}$ Henry Bacon (1994), Continuity and Transformation - the influence of literature and drama on cinema as a process of cultural continuity and renewal. Helsinki: Suomalainen Tiedeakatemia. p.33.

${ }^{3}$ Ibid., p.34.

${ }^{4}$ Ibid., p.32.

${ }^{5}$ Rod Whitmaker (1970), The Language of Film. New Jersey: Prentice-Hall, Inc.. pp.58-9.
} 
camera also can work miracles through juxtaposition of shots, which, "like the hieroglyphs of a Chinese ideogram, could result in something entirely new, an idea greater than the sum of its parts." ${ }^{\circ}$ With their capacity in framing the scenes in various angles, camera shots show its powerful potentiality in changing the meaning of the content in its framework. The frame helps to unearth, particulate and accentuate relationships of characters. All these elements brought in by camera work together, "rewriting" inevitably the meaning of screen plays.

Because of this, film adaptation inevitably becomes a process of critical selection, which makes screen presentation implicitly a work of literary criticism. According to Neil Sinyard, screen can stress what is believed to be the main theme of a given text, selecting certain episodes and excluding others, offering preferred alternatives, focusing on specific areas of the original, expanding and contracting details and having imaginative flights about some characters, thereby shedding new light on the original script. ${ }^{7}$ With the editing function of the camera in magnifying and narrowing down, focusing and attenuating, dissecting and reforming the content, screen adaptations turn to be an extension and recoding of stage plays. The very process from the stage script to the screen presentation demonstrates an interesting extension and variation of meaning under the effort of camera shoots.

\section{StAgE Play OF RosencrantZ AND GUILDENSTERn ARE DEAD}

In its basic dramatic structure, Tom Stoppard's Rosencrantz and Guildenstern Are Dead stands as the inverse of Hamlet: its title characters, Rosencrantz and Guildenstern (Ros and Guil), are two minor figures from Shakespeare's Hamlet, who are sent by the king to spy on the prince and later beheaded in England. In Stoppard's play, Ros and Guil are made the leads while the tragic hero Hamlet is reduced to a minor figure only playing a small part in the play. Building its plot on the misadventures and musings of Ros and Guil, the play dramatizes the lives of the two ill-fated friends who get entangled in the puzzling web of Hamlet's tragedy.

The stage play begins with one of the most memorable scenes in the twentieth century theatre: Ros and Guil are betting on the toss of coins while traveling toward Elsinore, the castle of Danish King Claudius. Guil feels puzzled and dazed with his bad luck in the game, which is exclusively the "head" against him in all the ninety two times. As they try to decide in which direction they have to travel, they hear music, and then see some Players or tragedians come as what happens in Hamlet. After that, the Players and tragedians become frequent presence on the stage, joining Ros and Guil now and then in their philosophical conversations on life and drama.

In Act II, the life of Ros and Guild in reality gets increasingly mixed with the scenes and dialogues from Hamlet. Shortly after Ros and Guil's discussion with the Player, Hamlet and Ophelia suddenly appear on the stage and mime the scene from Hamlet in which Ophelia is sent to test on Hamlet. The following moment sees the scene in which Gertrude and Claudius greet and welcome Ros and Guild in the language of Shakespeare, confusing the two in names. Instructed by the king to "glean" what afflicts Hamlet, Ros and Guil attempt to cross-examine the prince. But during this process, in the intervals of the episodes of Hamlet, Ros and Guild also fall now and then into discussions about the purpose of life. But their talking seems ending up only in worse confusion, for they just cannot make out what is going on around them. In this way, they pass the time, talking, flipping coins, and playing word games till the end of the second act with references to the season of autumn and Ros and Guil preparing to escort Hamlet to England.

Act III opens in pitch darkness with soft sea sounds and sailors' voices indicating that Ros and Guil are on a boat. It is soon discovered that the tragedians are on the boat too, hidden in the barrels. During their talk, the Player launches into a more philosophical speech: "life is a gamble, at terrible odds - if it was a bet you wouldn't take it." Then pirates attack the ship as what is written in Hamlet. When the fight is over, Ros and Guil find Hamlet is gone, and the letter to the king of England had been substituted by the prince, instructing the King to put the letter bearers to death. The play ends with the last scene from Hamlet, in which, with the bodies of the king, queen, Laertes and Hamlet lying on the stage, the Ambassador from England reports that Ros and Guil had been executed as the letter requested.

The premier of this play in 1967 immediately established Stoppard's position as a distinguished playwright. Harold Hobson, one of the most influential dramatic critics at that time, gave the play great applause, calling its presentation the most important event in the British professional theatre of the past nine years since Harold Pinter's The Birthday Party in 1958. And just like what happened to Pinter's early works, Rosencrantz and Guildenstern Are Dead was also labeled as a "Absurdist" play as soon as it came out, being associated with Samuel Beckett's Waiting for Godot. Some critics suggested that Stoppard had put Waiting for Godot inside Hamlet, taking the play as an "existentialist" work. But no matter how diversified people's interpretation of the work is, the motif of Stoppard's relation with Shakespeare becomes one of the most exciting and significant issues of research. Even the existentialist theme mentioned above is mainly articulated through the fate-like influence of Shakespearean script on Ros and Guil.

Compared with the subsequent film, the 1967 stage play relies mainly on its verbal strength, e.g., word games, speeches and dialogues. Focusing on the two minor characters sent to death in bewilderment, the play dramatizes their desperate resistance facing the mysterious fate-like hold of the pre-set narration in Shakespeare's written script. As Delaney notices, "In Rosencrantz and Guildenstern Are Dead, the courtiers' attempt to understand their fate is greeted by the Player's pronouncement: 'It's written'. Such biblical language has the effect of associating, within the created

\footnotetext{
${ }^{6}$ Stuart Y. McDougal (1985), Made into Movie: Literature to Film. New York: Harcourt Brace College Publishers. p.340.

${ }^{7}$ Henry Bacon (1994), Continuity and Transformation. P.32.
} 
world of Stoppard's play, the Shakespearean text with the Scriptural."8 In illustrating the characters' helpless fight against the hold of Shakespearean biblical text on their fate, the play also reveals the motif of the dramatist's own postmodernist relation with Shakespeare's classic.

From the beginning of the play, Ros and Guil seem to be aware of a mysterious spell on them, and try painfully to prove that they have influence on things and are capable of a logic sense of direction in life. The conflict between the hold of the spell and their resistance against them eventually works as a central line in the play. Significantly, Ros and Guil are clearly defined in the stage play as two Elizabethans (from Shakespeare's world) at the beginning of the play. When the curtain rises, they are betting on the toss of the coins. Facing the result of being exclusively the "head" against him in all the ninety two times, Guil is deeply shocked and puzzled by the unusual bad luck and its implication. He vaguely feels the tight hold of some spell on them: he gets up but has nowhere to go. So, in the following several minutes, Guil tries first to explain and justify the phenomenon with syllogisms. And then, to solve the riddle, he also looks back in the past, intending to trace back to the initial moment of memory for an answer, only to find that their present situation starts with "a message", a summons which is given by the king as what is written by Shakespeare in Hamlet.

Compared with his image in the later screen play, Guil, the more intelligent and inquisitive of the two, is portrayed as being more violent in the stage work. He smashes the Player when the latter asks him to take part in the performance of the vulgar play. He shows such fury not so much for an insult to his dignity as for an association of them with acting under the thumb of some written words. As he tells the Player, he might have been a bird out of season, a tongueless dwarf, but still he is "standing by the road to point the way" (21). Just like the poetic image in his previous speech of a man seeing a unicorn crossing his path and disappearing, Guil is implying that he knows the direction of his way, and he has capacity of having an influence. As they are increasingly dragged into the Hamlet plot, Gui's attempt to "have influence" gets expressed through a series of philosophical speeches like this and word games with Ros. In playing the games, he is just to sort out the "logic at work" (30) and "the direction of the wind" (43). As he tells Ros: "Wheels have been set in motion, and they have their own pace, to which we are ... condemned. Each move is dictated by the previous one- that is the meaning of order" (43).

The crucial point is that in his searching for the direction of wind, Guil is frequently found not looking forth but back. Since the first time he asks Ros about "What's the last thing you remember?" (44), he has been secretly wishing to be back to the world before that "summons" and being dragged into the realm of the written words. In his speech, he expresses his envy of the Chinese philosopher, Chuang Tzu, who "dreamed he was a butterfly, and from that moment he was never quite sure that he was not a butterfly dreaming it was a Chinese philosopher"(44). What Guil envies of Chuang Tzu is his freedom of shuttling through the bound of the two worlds. It is not until later when we realize that the starting point of their journey they try to return is the set plot in Hamlet by Shakespeare. But while he wishes to be back, he is desperately aware of his situation of no-returning, no escaping from the present realm of "words": "We cross our bridges when we come to them and burn them behind us, with nothing to show for our progress except a memory of the smell of smoke" (44).

If Guil's resistance to the mysterious spell on them finds expression in his attempt to explain the phenomenon, Ros's is shown in his simple desire to "go home" as well as his impatience with the intruding of the Shakespearean characters from Hamlet. When the royal procession comes and disappears for the first time in Act One, leaving them on the stage as if nothing had happened, Ros says, "I want to go home" and "I'm out of my step here" (29). By the phrase of "go[ing back] home", it means returning to the moment before being summoned and being free from the spell. While Guil struggles for a direction, Ros knows clearly well that their direction is backward, in the direction to home: "I want to go home. (Moves) Which way did we come in?" (30) Unlike Guil, Ros has no interest in the things around him; instead, he is playing the game throughout the play. But in the views of Stopaprd, it is just this simplicity in Ros that makes him closer to truth than Guil: as Ros says, "He murdered us." In the second half of the play, he frequently talks of death: "Do you ever think of yourself as actually dead, lying in a box with a lid on it?" (51) Though less in words, Ros seems knowing well what is the invisible spell that Guil tries hard to clarify: it is nothing but the imposing presence of Hamlet plot on them. In the play, he is found twice on the verge of tears. Facing the coming and going of the Hamlet figures, he cries bitterly: (Near tears) "I'm not going to stand for it!" But just at this moment, a female figure, ostensibly the queen, enters. Ros marches up behind her, puts his hands over her eyes and says with a desperate frivolity. Ros's gesture of frivolity to the supposed queen reveals the same despair as Guil's violence to the player who invites them to the play. All his intolerance towards the intruding Shakespearean figures is expressed in his sentence of "I am only glad that that's the last we've seen of him" (68).

Besides the dilemma between Guil's attempt to see the direction and their awareness of having no road back to their original selves, another dramatic tension in the play is the counter force from the world of the players imposed on them. While Guil tries hard to prove that he can have an influence, the very presence of Players suggests the blurring of the line between life and dramatic text. As the Player depicts their work of acting, "We keep to our usual stuff, more or less, only inside out. We do on stage the things that are supposed to happen off. Which is a kind of integrity, if you look on

\footnotetext{
${ }^{8}$ Paul Delaney (1990), Tom Stoppard: the Moral Vision of the Major Plays. Basingstoke, Hampshire: Macmillan. p.34.

${ }^{9}$ Tom Stoppard (1967), Rosencrantz and Guildenstern Are Dead, London: Faber and Faber. p.21. Subsequent documentation of quotations from this play will be in-text notes within parentheses.
} 
every exit being an entrance somewhere else" (22). So, when Guil asks him if he is to change into his costume, his answer is "I never change out of it" and he is always "in character" (26). This ironically foretells the situation in which Ros and Guil are: being aware of it or not, ever since their life was written down by Shakespeare, they have never been out of their "costume". And this implication is also illustrated through the symbolic image of the actor Alfred, who is found to be frequently half in and out of the robe while the Player and Guil bet. All these suggest the mutual identification of the worlds offstage and onstage. The only difference between the Player and Ros and Guil lies in that the Player accepts his dramatic role while Guil and Ros refuse to be so, insisting to be mere spectators instead of figures in the play:

Player: ...There's a design at work in all art—surely you know that? Events must play themselves out to aesthetic, moral and logical conclusion.

Guil: And what's that, in this case?

Player: It never varies — we aim at the point where everyone who is marked for death dies.

$\cdots$

Guil: Who decides?

Player: (Switching off his smile) Decides? It is written....we're tragedians, you see. We follow directions - there is no choice involved. The bad end unhappily, the good unluckily. That is what tragedy means. (Calling) Positions! (59)

To the Player, scripts are like fate-like words of biblical status. In the textual world of drama, "It is written" means "it is unchanged". It is just this terrible truth shown in the Player that Guil feels dread. So he insists on a distance from "art" - "we don't know how to act... we only know what we're told, and that's little enough" (49) —and demands a freedom from what is set down in the "text".

Unlike what happens in the film in which Ros and Guil shuttle freely in the symbolic palace of Shakespeare's world, Ros and Guil in the stage play are totally passive, with Shakespeare's characters coming and going, throwing their presence on them while they can do nothing but bear it in rage and desperation. When they are betting with the Player, for example, suddenly Ophelia runs on the stage in some alarm, being followed by Hamlet; and then with a flourish, enters Claudius and Gertrude attended by their courtiers. This drives Ros and Guil increasingly to desperation. Near the end of Act Two, Ros irritably cries, “They're taking us for granted! Well, I wont' stand for it! In future, notice will be taken. (He wheels again to face into the wings.) Keep out, then! I forbid anyone to enter! (No one comes-Breathing heavily.) That's better..." (53) But the moment his words are spoken, ironically, an even bigger procession enters, principally Claudius and Gertrude. And to his shock, Clauiud takes his elbow as he passes and is immediately deep in conversation with him: the context is Act III, scene $\mathrm{i}$ in Shakespeare. And in the following several minutes, audience find that Hamlet enters upstage, as if being wholly unaware of the presence of Ros and Guil. When they eventually disappear into the wing, Ros exclaims hopelessly, "It's like living in a public park!"(55) Scenes like this demonstrate vividly how Shakespeare's world imposes its presence on them. When this takes place, the dividing line between Shakespeare's play and reality totally disappears.

So, though Shakespeare's tragic world gets subverted in Stoppard's stage play, nevertheless, one cannot find the excitement and release of the real subversion in the stage script. Instead, what people feel far more strongly is the suffocating hold of the spell of Shakespeare on Ros and Guil, the sense of imprisonment from the prior text, and their hopelessness in resistance. In this way, for all his post-modernist misuse of Shakespeare's classic, Stoppard seems being unconsciously putting Shakespeare on an insurmountable level.

\section{NEW LIGHT THAT SCREEN BRINGS TO ROSENCRANTZ AND GUILDENSTERN ARE DEAD}

Re-working the stage play into a screen work in 1991, Stoppard felt strongly the time distance between the two versions: "it [the stage play] was written 25 years ago and not all of it is still to my taste." "Therefore, in writing the screen script, he said

I left out half the lines [in stage play]. It's a play about two people waiting for other people to come in and go out, and the energy of the piece has to be carried mainly by the language. In the movies they aren't trapped like that: they can do the rushing about - which is what happens. In the play it's like two people on a railway platform, and in the film they're roaring around like this train. So there's a lot of energy that gets used in the physical momentum of this. ${ }^{11}$

So, when the film came, it appeared in a strikingly fresh form: dialogues are shortened, simplified and some are even deleted. There are far more settings and the play is quicker in rhythm. Relying on the shifts and juxtaposition of shots, montage technique, audio effect of music, the film creates an eerie and mysterious mood that the stage is unable to achieve. With all these changes, the meaning of the screenplay gets eventually re-written, particularly in the aspect of its relationship with Shakespeare's Hamlet.

In the stage play, the focus of dramatization is on Guil and Ros's sense of spell of the pre-set plot of Shakespeare's text on them, and the futility of their resistance to its ultimate hold. In the film, this central line is only partly preserved: with the help of camera perspective, Stoppard gives his characters more freedom and capacity in counteracting Shakespeare's Hamlet. The result is that although the image of Shakespeare's biblical dramatic text still haunts the story

\footnotetext{
${ }^{10}$ Paul Delaney (1990), Tom Stoppard: the Moral Vision of the Major Plays. P.235.

${ }^{11}$ Ibid.
} 
like a ghost, a carnival air of absurdity is added to the tragic story of Ros and Guil, which makes Stoppard's motif of Shakespeare more ambiguous.

First of all, the screen version introduces a fabulous air of modern thrillers. Unlike what happens in the stage play, Ros and Guil are portrayed like two horsemen or cowboys instead of Elizabethans. When the movie begins, they emerge gradually like two black spots from the distance to the screen. And the following pictures of their leisure walking in the woods, camping and eating hamburger all give them an air of modern time. With the help of modern movie technique, Stoppard, the playwright as well as the director, gives the screen work a fantastic air of strain. The very manner of Ros and Guil entering the Shakespearean world proves to be like that: First, it is some woman's wailing voice filling the air like a ghost from some locked castle in legend; and the next moment, Ros and Guil find themselves in the Painted Hall, where they will experience many scenes from Hamlet in the following part of the movie. With a window curtain dragged down by Ophelia and Hamlet falling over the heads of the dazzled Ros and Guil who just entered, the two start their adventures in the Shakespearean world.

The greatest change from stage play to the screen work lies in that the flexibility of camera shots gives Ros and Guil not only more spatial freedom of movement, but also a detached stance of observation, which is almost impossible to achieve on the stage. In the screen play, only now and then they are found involved in the Shakespearean story from which they come; most of the time, they are just detached observers, enjoying the freedom given by camera. Here unlike in the stage play, Ros and Guil are longer imposed passively with the presence of Hamlet figures. Ros and Guil walk into the Shakespearean "castle" by themselves in a highly fantastic way; and there, they find a symbolic existence of Shakespeare's world as a castle-palace with corridors, staircases, cellars, trapdoors, and gallery hall, which are linked with doors, through which they shuttle freely, tracing the voices and scenes of the great story. They run up and down the staircases, in the barns, the kitchen and every other corner of the Shakespearean castle, watching the scenes of Hamlet from the angle of the camera shots as audience.

And with the help of camera shots, Ros and Guil's role as audience is further achieved through a series of effective visual images - the windows from which they watch the scenes in Hamlet, the upper stairs from which they witness what happens in the Painted Hall, the echoing voice they hear when speaking in the hall, and the pipe line along which Guil listens to the performance of Shakespeare in the kitchen of the castle. The first time when the image of window appears is in the scene of badminton court: while playing word game in the manner of badminton, Ros and Guil open a window and see the player's cart outside. Since this moment, the image of Ros and Guil watching the dramatic scenes in Hamlet through the windows becomes a symbolic picture to illustrate their relation with Shakespeare's text. Because immediately after the scene in the badminton hall, the camera finds Guil and Ros in a corridor, a place of echoing footsteps, where Guil stands listening and watching. Looking through the window bars, he sees the scene of Polonius telling Claudius that his daughter might be the origin of Hamlet's madness. A few minutes later, they suddenly hear a voice from somewhere in the castle. Following the voice to a small window and looking through it, they find they are looking from above into a large kitchen: the players are giving a rehearsal to an audience including Hamlet and Polonius. In this fabulous way Ros and Guil run through the corridors, staircases, doors, tracing vague voices or pausing now and then to watch a scene from Hamlet. Of course, there are some scenes in the film suggesting Ros and Guil's involvement in the play: for example, in the scene when they are watching Hamlet and Polonius, the prince suddenly notices their presence and tells them "leave me, friends". ${ }^{12}$ Moments like this pull Ros and Guil from the deportment of observers to participants. But the feeling of distance brought by the image of windows is accentuated in the scene after they watch rehearsal in the kitchen. In that part, they continue to hurry down the stair to a landing. The player's performance can still be heard there. While Guil puts his ear to a drainpipe to listen all the better, Ros finds a trapdoor. The very image of the pipe against which Guil listens to what happens in the play, particularly the distortion of voice when water gurgles down the pipe, strongly suggest how they are watching Shakespeare over the great span of history and what change that flow of time brings to the meaning of the story.

Endowing Ros and Guil with the role of audience, the film highlights audience's function in the creation of meaning. In the screen work, the minor ideas in the stage play get enlarged into a long scene in the barn, in which a rehearsal of Hamlet is given to an audience of servants. In the process of the players performing the tragedy, the camera pans frequently between the graceful scenes of Shakespeare's play on the stage and the crude laughter, loud applause, and vulgar facial expression of the servants offstage. Not to mention the funny effect resulted from the mixture between the elegant music of the play and hen's voice and baby's cry in the barn. With the final image of the two spies in Hamlet dangling on tiptoe on the stage and the servants applauding loudly, a crude carnival element is introduced to the canonic tragedy world - the vulgar and the serious are roughly put together. In fact, this kind of carnival treatment of Shakespeare's tragedy in the manner of Bahktin's theory becomes a dominating mood in the film.

According to Bahktin, carnivalism originated from the mediaeval ritual of festival, in which the social order is temporarily destroyed, with the sacred and the serious being dragged down from their normal throne while the insignificant and the clowns being raised to the level of the great. So, the essence of carnivalism lies in its nature of the subversion, a violation of the normal expectation of the proper social order. In the film, for several times, the king is portrayed as a clownish frivolous figure. In the scene when Guil is meditating philosophically of "Your smallest action

\footnotetext{
${ }^{12}$ Tom Stoppard (1990), Rosencrantz and Guildenstern Are Dead The Film, London: Faber and Faber. p.52. Subsequent documentation of quotations from this film will be in-text notes within parentheses.
} 
sets off another somewhere else, and is set off by it" (17), the king and queen suddenly surge into the Paint Hall in a highly unceremonious manner: he takes off his crown and tosses it to her, and then in the same flippant way she takes it. The similar carnival air is also found in Stoppard's portrayal of Shakespeare's tragic hero, Hamlet. In the scene of his dining with Ros and Guil, Hamlet suddenly jumps up the table and begins to deliver the famous passage in a highly exaggerating way: "I have of late, but wherefore I know not, lost all my mirth" (31). By the time he utters the sentence of "but it appeareth nothing to me but a foul and pestilent congregation of vapors" (31), he has crawled along the table and got back to his chair. Then he picks up his cup and belches loudly. In scenes like this, the sacred and serious is dragged down from its highest status to a clownish position like in a carnival ritual.

Besides the carnival air, another subversive approach the film brings to the Shakespearean figures is the introduction of the image of modern science into the play. The most impressive scene is how Ros transforms a piece of [Shakespeare's] manuscript into a paper bi-plane. Through this symbolic picture, Stoppard is actually demonstrating his post-modernist approach in his rewriting of Shakespeare's plays and the new perspective he brings to the classic. Significantly, it is Ros, the simpler one of the two, who is given the role of carrying forth all the scientific attempts in the movie. Compared with Guil who is always deep in brooding and questioning and leading their word games, Ros is less rational and more intuitive. But for some mysterious reason, it is Ros who is made by Stoppard to stumble on the scientific discoveries. In the gallery and badminton scenes, for example, he tries to juggle first, but fails. Then, he finds the interesting game of throwing a loose feather and a croquet ball—as Stoppard jokingly writes in his script instruction "He is within an ace of getting there in front of Galileo" (19). In another scene in the garden of the fruits where an apple tree stands, Ros's eyes fall on a line of spherical earthenware pots hanging from a branch: he "gives the first pot a swing and find that the one at the far end is nudged out of position by the impact"(28). Though unaware of what he is doing, as Stoppard states it, Ros is definitely intrigued by the "Newton's Cradle" phenomenon, which he falls into instinctively. The same simple genius is later found in his Archimedes' discovery in the bath house. When Ros raises himself out of his bath, he notices that in doing so, he has lowered the water level as indicated by his toy boat floating on the surface. While he lowers himself, the boat rises again to the former mark. Here, as Stoppard says, Ros is again about to rediscover Archimedes' principle. The very association of Ros' innocent genius with the image of apple tree in the garden gives Ros a greater symbolic meaning: though intellectually less quick than Guil, Ros's innocent intuition makes him closer to truth.

So, a significant change in the film is the shift of the truth pursuer from Guil to Ros. In the stage play, Stoppard's focus seems to be on Guil who is portrayed as a parody on the tragic Hamlet, who feels trapped by an ineffable spell and tries hard to break it. But in the film, Guil is portrayed as rude, violent and proud. As a contrast, Ros is presented as humane, emotional and simple: he not only stumbles upon scientific discoveries, but also proves his smartness in obtaining the truth about human relationship around him. After their dinner scene with Hamlet, Guil say, "I think we can say we made some progress" (33). To this, Ros expresses a different view: “... he made us look ridiculous...Hamlet was scoring off us all down the line" and "He murdered us" (33). This is a typical example of how his silent observation turns out to be an insightful perception of the situation they are in. It is also Ros who eventually perceives their doomed fate of death. Lying on the top of a stone tomb in Act Three, Ros asks Guil who is talking about in the room, "if I asked you straight off-I'm going to stuff you in this box now, would you rather be alive or dead?" (46) Here, his sentence not only blurts out the truth of the situation (living death) they are in, but also explains the reason why he shows no interest in struggling for the direction or the logic of things as Guil does. As he says, "there's only one direction and time is its only measure" (47). When he throws the paper bi-plane to Guil, he is almost symbolically showing the latter the destination of their fate. By showing the paper plane which is made of the manuscript, Ros is demonstrating to Guil that for all the change from the script to paper plane, the essential substance is the same. The further implication of his gesture is that though greatly changed they have been-from the two minor characters in Hamlet to the protagonists in Rosencrantz and Guildenstern Are Dead - their fate will remain the same. Actually, the very picture of bi-plane stands as a paradoxical image: on the one hand, the paper bi-plane shows the fantastic re-creation from the manuscript; but one the other hand, it also can be understood that, no matter what a modern feeling the image of the plane gives us, it is still made of the script paper from the mysterious source. The implying meaning is that however changed they have been, Ros and Guil must die because, in the Player's word, "It is written" long before in Shakespeare's plays (50).

So, the movie of Rosencrantz and Guildenstern Are Dead demonstrates a more ambivalent and contradictory attitudes of Stoppard towards Shakespeare than the previous stage play: on the one hand, the film treats the Shakespearean mother-text more subversively with the detached perspective of the camera, but on the other hand, it also seems strengthening the haunting presence of the long-dead precursor through a series of ghost images, which constantly remind the audience of the presence of Shakespeare's scripture. While the movie is prevailed with a carnival air of comedy, it is also haunted by an eerie gothic atmosphere at the same time.

An air of invisible supernatural force permeates the whole movie. Though the messenger sent by the king to Ros and Guil has been mentioned in the stage play, the verbal medium does not gives much stress on the mysterious image fully. But in the film, the camera creates an unusually shocking effect about the image of the messenger through its visual power. In the flashback that repeats three times throughout the whole work, the camera shoots a certain wooden shutter, seen from the inside of a dark room where Ros and Guil are supposed to stay. With the shutters being banged and shaken violently, an echoing voice is shouting their names. Then the shot moves to Ros and Guil who abruptly stand up, 
shocked as if receiving some urgent summons from above, exclaiming nervously, "We were sent for" (6). The strikingly contrasting scenes of the flash - the dark room and the light outside separated by the wooden shutters-invite audience to have a symbolic understanding of the words said by Ros and Gui: "pale sky before dawn, a man standing in his saddle to bang on the shutters ... he called our names....this man woke us up" (7). The particular time of "before down" and the messenger's posture of "standing in his saddle" in the dazzling light outside remind people of some holy messenger from above. More significantly, the next moment, they hear the distant rhythmic iron clank of the players' cart. With the tragedians' presence, Ros and Guil's journey [pre-set by the Shakespearean text] begins. The particular context created by camera shots invites the strong association of Shakespeare's world with the mysterious presence from above.

This implied motif of Stoppard's relation with Shakespeare gets particularly accentuated through the haunting presence of the manuscripts flying in the sky. The image of manuscripts appears on the screen for the first time after Ros and Guil's encounter with the tragedians in the woods and before they enter into the Hamlet world of the Castle. In an eerie way, some loose pages of manuscripts are seen fluttering out from an open box of the players, being blown one after another like spectra. The similar eerie feeling appears again when Ros and Guil are in the Painted Hall, where for a moment they see Hamlet and Ophelia, but in a blink of eye's time they find the Hall is empty with no one in it. It is after that on the screen appears again the loose pages of manuscripts blown along the floor-in the same desolate and haunting way. Like the bi-plane, the haunting image of the script is also paradoxical—while it shows that Shakespeare's plays had been dead long ago, it also suggests they are still present with their invisibly shaping hold on everything in it.

The haunting presence of Shakespeare's play is further illustrated through the image of the windows, through which the camera frequently catches Ros and Guil watching the figures from Hamlet. These windows not only visualize the detached posture of Ros and Guil, but also suggest the situation of confinement the Hamlet figures are in.

Actually all the figures from Hamlet are presented like imprisoned ghosts in Stoppard's movie. In one of the scenes, Guil shouts loudly to Ros, whose voice echoes in the castle and brings Ophelia to a window. When the camera shots her face beyond the grille, she looks like a ghost figure locked in the dark rooms of the past. In another scene of a cobwebbed derelict chamber, the setting, like the eerie wailing voice of woman and the fluttered manuscripts, gives the audience the feeling of death. In a setting like this, figures are more like haunting images than real people. In fact, in spite of their rushing about in the castle, Ros and Guil are also portrayed as prisoners in it. For twice, the camera presents Ros and Guil as characters beyond the grilles. Once is when they are standing outside the cobwebbed chamber, watching Hamlet in it; the other is when Hamlet is delivering "to be or not to be", the camera shoots Claudius, Polonius, Ros and Guil standing beside the window watching to the inside. In such scenes, the camera takes them through the grille, giving people a strong illusion of that they are people behind the bars.

So, the essential identification of the players' world with Ros and Guil we find in Stoppard's stage play is still here in the movie. Ros and Guil are still playing "word games" (the same work that the players do on the stage). The most important "word game" is to question "Hamlet", whom Guil pretends to be. And some images in the film suggest the blurring between the players and the supposed characters in reality. For instance, in the scene where Ros makes the paper plane, Guil walks about in the room. Then he hears some voices, and following them, he reaches to a door, which has a small hatch. Opening it, he is shocked to see a masked face facing him outside, an actor who is adjusting his mask in a mirror on the door. But the cross shots from Guil to the masked actor, and from the actor to the face in the mirror suggests strongly the mutual identification between the two. It shows that there is no difference between the people outside and inside the door. Moreover, the following long shot of the puppet performance makes this point even more obvious: while the puppet Hamlet is presented on the stage, among the audience sit the identically masked King and queen. The closed-up of the camera on the facial expression of the masked Queen shows how she recognizes another self in the puppet queen on the stage. These identifications eventually develop into a real verging of the stage and offstage worlds when Ros and Guil are found on the same "boat" with the tragedians to England: "It never varies-we aim at the point where everyone who is marked for death dies" (49).

In the end of the film, Ros and Guil have been wholly back to their roles preset in Shakespeare's Hamlet. Here, again, the camera shows its advantage of juxtaposition of shots. After the camera dissolves into a series of Hamlet scenesOphelia gets drowned, Leartes wounds Hamlet, Gertrude falls dead, and Hamlet kills Claudius - the audiences see that Ros and Guil are standing in front of them, with robes round their necks. So far, the beginning and the ending of the film seem having run a circle. It begins with Ros and Guil riding into the view of the camera, and ends with the picture of the two figures with rope round their necks and at the same time the players packing up their things, and then in the eerie music - half sad and half funny - the cart driving to the deep of the dark wood, to the direction opposite to the camera and the direction where Ros and Guil come from. For a moment, it seems as if what the audience saw in the past two hours had never happened. All the figures, Ros, Guil as well as other Hamlet characters, were once again put back into the box of the manuscript on the cart of the players after a haunting visit to the screen. This highly symbolic picture powerfully suggests that though the camera turns Ros and Guil into detached audience temporarily, Shakespeare's manuscript will eventually draw them back into their theatrical roles.

So, compared with the stage play in 1967, the 1991 film presents something totally new from Shakespeare's canonic text, but still something essential has been preserved: just like what the paper plane shows, although the film is so modern that one can hardly trace any sign of the original Elizabeth air of tragedy, nevertheless, nevertheless, it still 
cannot change one fact, e.g., the paper plane is one made of the manuscript no matter how fantastic it has been made. As the running-on scenes of the aero-plane and the next one-Guil opens the hatch on a door and sees a masked face facing him-illustrates, Ros and Guil's eventual identification with the figures in the play underlies the camera's revolutionary perspective of subversion. From this image, one might detect the contradictory feelings of external rebellion but internal acceptance that Stoppard bears towards the canonic text of Shakespeare.

\section{REFERENCES}

[1] Bacon, Henry. (1994). Continuity and Transformation - the influence of literature and drama on cinema as a process of cultural continuity and renewal. Helsinki: Suomalainen Tiedeakatemia.

[2] Delaney, Paul. (1990). Tom Stoppard: the Moral Vision of the Major Plays. Basingstoke, Hampshire: Macmillan.

[3] McDougal, Stuart Y. (1985). Made into Movie: Literature to Film. New York: Harcourt Brace College Publishers.

[4] Stoppard, Tom. (1967). Rosencrantz and Guildenstern Are Dead. London: faber and faber.

[5] Stoppard, Tom. (1990). Rosencrantz and Guildenstern Are Dead the Film. London: faber and faber.

[6] Tornqvist, Egil. (1991). Transposing Drama. Basingstoke: Macmillan.

[7] Whitmaker, Rod. (1970). The Language of Film. New Jersey: Prentice-Hall, Inc.

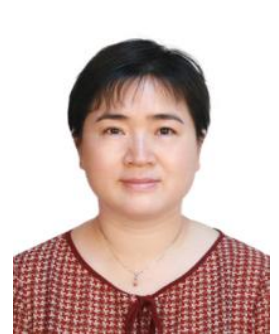

Hongwei Chen was born in Henan, China, on $15^{\text {th }}$ July, 1966. She received her BA in English in Guangzhou Foreign Languages Institute (1987), MA and $\mathrm{PhD}$ in English and American literature in Beijing Foreign Studies University $(1993,2005)$, China, and her $2^{\text {nd }}$ MA in English literature in Leeds University (2004), England.

She has been working as a teacher in the English Department of Beijing Science and Technology University since 1993, teaching various literature and culture courses for the undergraduates and MA students. She had published in the past three years such academic works as Harold Pinter in the Post-War English Drama (monograph, Beijing: University of International Business and Economics Publisher, 2007), History of Contemporary English Drama (second author. Beijing: Beijing University Publisher, 2007), 20 ${ }^{\text {th }}$ Century English Drama (Beijing: Beijing University Publisher, 2009). Her current research interests lie in the $20^{\text {th }}$ century English and American drama.

Dr. Chen is a professor of the School of Foreign Studies in USTB now. 